\title{
Bacterial Load of Clostridium Perfringens in the Aquatic Environment of Dal Lake, Kashmir
}

\section{Mehak Hafeez ${ }^{1}$, Irfan Ahmad ${ }^{1 *}$, Sabia Qureshi' ${ }^{2}$, Zahid Kashoo ${ }^{2}$, Shaheen Farooq ${ }^{2}$, Shakeel Wani ${ }^{2}$, Oyas Asmi ${ }^{3}$, Feroz Shah ${ }^{4}$, Bilal Ahmad $^{5}$, Farooz Bhat ${ }^{6}$, Sumaira Rashid ${ }^{1}$, Hussna ${ }^{1}$ and Nakeer Razak ${ }^{1}$}

${ }^{1}$ Division of Fish Genetics and Biotechnology, Faculty of Fisheries, Sher-E-Kashmir University of Agricultural Sciences and Technology of Kashmir, India

${ }^{2}$ Division of Veterinary Microbiology and Immunology, Faculty of Veterinary

Sciences and Animal Husbandry, Sher-E-Kashmir University of Agricultural Sciences and Technology of Kashmir, India

${ }^{3}$ Division of Fish Nutrition and Biochemistry, Faculty of Fisheries, Sher-E-Kashmir University of Agricultural Sciences and Technology of Kashmir, India

${ }^{4}$ Division of Fish Health Management, Faculty of Fisheries, Sher-E-Kashmir

University of Agricultural Sciences and Technology of Kashmir, India

${ }^{5}$ Division of Social Sciences, Faculty of Fisheries, Sher-E-Kashmir University of

Agricultural Sciences and Technology of Kashmir, India

${ }^{6}$ Division of Fisheries Resource Management, Faculty of Fisheries, Sher-E-Kashmir

University of Agricultural Sciences and Technology of Kashmir, India

*Corresponding Author: Irfan Ahmad, Division of Fish Genetics and Biotechnology, Faculty of Fisheries, Sher-E-Kashmir University of Agricultural Sciences and Technology of Kashmir, India.
Received: January 30, 2020

Published: February 08, 2020

(C) All rights are reserved by Irfan Ahmad., et al.

\section{Abstract}

The study was aimed to investigate the presence of Clostridium. perfringens (C. perfringens) and estimate its bacterial load in the aquatic environment of the Dal Lake, Kashmir. A total of 45 water samples ( 9 from each site) were collected randomly from 5 different sites viz., Dhobi Ghat, Telbal Nallah, Char-Chinari, Centaur Lake View and Dalgate of the Dal Lake. Using species-specific $16 \mathrm{~S}$ rRNA gene amplification, all the $45(100 \%)$ water samples were found to be positive for $C$. perfringens confirming the presence of $C$. perfringens in the lake. The overall C. perfringens load in water samples was found to be in the range of $9.2 \times 10 \mathrm{CFU} / \mathrm{ml}$ to $1.87 \times 10^{2}$ $\mathrm{CFU} / \mathrm{ml}$, which is much less than the critical CFU level of $C$. perfringens $\left(10^{5}-10^{8}\right)$. The highest average $\mathrm{CFU} / \mathrm{ml}$ value was found at Dalgate $\left(1.87 \times 10^{2}\right)$, followed by Telbal Nallah $\left(1.78 \times 10^{2}\right)$, Dhobi Ghat $\left(1.20 \times 10^{2}\right)$, Centaur Lake View $\left(1.05 \times 10^{2}\right)$ and Char-Chinari ( $9.2 \times 10)$, respectively. Statistically, it was observed that there is a significant difference in average CFU/ml values of $C$. perfringens at the five sites of the lake $(\mathrm{P}<0.01)$. The current study documented the presence of $C$. perfringens in the aquatic environment of the Dal Lake for the first time in the Kashmir valley.

Keywords: C. perfringens; Anaerobe; 16S rRNA; PCR; CFU

\section{Introduction}

A large number of infectious diseases are transmitted primarily through water supplies contaminated with human and animal excreta [25]. There have been many outbreaks of water borne diseases at the global level but the situation is especially serious in developing countries due to their high prevalence and mortality [9]. 
The water borne pathogens that pose a serious human health risk whenever present in drinking water include C. perfringens, Salmonella spp., Shigella spp., Campylobacter spp., among many others [15].

C. perfringens is a Gram-positive, anaerobic, non-motile bacillus. Besides its cosmopolitan distribution, it is a normal inhabitant of human and animal intestines $[3,8,12,20]$. Under unfavourable environmental conditions, it generates highly resistant endospores [26]. C. perfringens is one of the most prolific toxin-producing bacteria, forming at least 20 distinct toxins [10]. Based on the toxins produced, there are 7 strains of $C$. perfringens viz; type A (alpha toxin), type B (alpha, beta and epsilon toxins), type C (alpha and beta toxins), type $\mathrm{D}$ (alpha and epsilon toxins), type $\mathrm{E}$ (alpha and iota toxins), type $\mathrm{F}$ (alpha toxin and enterotoxin) and type $\mathrm{G}$ (alpha and NetB toxins) [10]. All the isolates of $C$. perfringens produce alpha toxin [21].C. perfringens is believed to be the most wide-spread bacterial pathogen in nature responsible for causing a number of disease syndromes in humans and animals [16]. C. perfringens is also important as an indicator of faecal contamination in aquatic habitats from which the use of water for portable purpose can put human health at risk due to the production of various toxins affecting the nervous and gastrointestinal systems of the consumer [17]. The toxinfection usually occurs when the load of $C$. perfringens in water or food is above $10^{5}$ to $10^{8} \mathrm{CFU} / \mathrm{g}[13,14,20]$.

The aquatic resources in the valley of Kashmir have a considerable impact on the socio-economic status of the local people as they provide portable water and sustain commercial activities of fisheries, agriculture and tourism. However, these resources are facing grave pollution problems due to various anthropogenic activities notably the disposal of raw sewage and domestic wastes from catchment areas. These problems are more pronounced in lentic ecosystems like Dal Lake which has witnessed a terrible deterioration in its water quality over the past few decades [19] and the probability of $C$. perfringens in its waters is high. Dal Lake, one of the famous lakes of India with its pristine glory, is a source of potable and recreational water as well as a source of cheap, affordable protein in the form of fish [2]. Water of the lake is continuously being fed with human excreta through sewage dumping, although some partial treatment of the sewage is done via treatment plants. The lake is in a serious state of eutrophication mostly cultural and ways and means for lake restoration have not proved to be fruit full till date. The floating gardens of the lake that have originated with time have now assumed a status of biggest vegetable producing bowl of Kashmir. The polluted water acts as a carrier of viral transmission and since the lake is used as a sewage dump, a tourist hot spot and thus might act as a concentration tool for the bacterial propagation. It is pertinent to mention here that various pathotypes of Escherichia coli have been reported from diarrhoeic children of Kashmir [27].

\section{Materials and Methods}

\section{Sampling}

An urban water body, Dal Lake, located in Srinagar city at 1584 masl (latitude $34^{\circ} 07^{\prime} \mathrm{N}$ and longitude $74^{\circ} 52^{\prime} \mathrm{E}$ ) with total area of 11.4 sq. $\mathrm{km}$ and catchment area of $316 \mathrm{sq}$. $\mathrm{km}$, was selected for the current study [16]. Five 5 sampling sites were chosen in the lake: Dalgate, Telbal Nallah, Dhobi Ghat, Centaur Lake View and CharChinari. A total of 45 water samples ( 9 from each site) were collected in sterile plastic tubes and were transported to the laboratory for immediate processing.

\section{Isolation and identification of $C$. perfringens}

For isolation of $C$. perfringens, the water samples were inoculated into Difco ${ }^{\mathrm{TM}}$ Cooked meat medium (Becton, Dickinson and Company, USA) and incubated anaerobically in 3.5 litre anaerobic jars (Oxoid Limited, Thermo Fisher Scientific Inc., UK) with Gas$\mathrm{Pak}^{\mathrm{TM}}$ Anaerobe Container System (Becton, Dickinson and Company, USA) at $37^{\circ} \mathrm{C}$ for 48 hours. The enriched samples were then streaked on Sulfite Polymyxin Sulphadiazine agar plates (SPS HiVeg $^{\mathrm{TM}}$ Agar, Modified; Hi-media Laboratories, Mumbai, India) and the plates were incubated anaerobically at $37^{\circ} \mathrm{C}$ for 24 hours. After incubation, typical black centered creamish colonies suggestive of C. perfringens [23] were stained with Gram's stain and sub-cultured on the SPS agar plates until they were free from other contaminating bacteria. The pure cultures of suspected $C$. perfringens isolates were subjected to Gram's staining and then PCR for final identification.

An isolated colony was stained on a grease free clean glass slide using Gram staining kit (Becton, Dickinson and Company, Sparks, MD, USA). The violet coloured bacteria indicated the Gram positive bacteria while pink coloured indicated the Gram negative bacteria.

DNA extraction was done by boiling and snap chilling method [4]. Two to three suspected colonies from SPS agar plates were suspended in $1.5 \mathrm{ml}$ microcentrifuge tubes containing $100 \mu \mathrm{l}$ of distilled water by gentle vortexing. The samples were boiled for 10 minutes, cooled on ice for 5 minutes and centrifuged at 13,000 $\mathrm{rpm} / 10,000 \mathrm{xg}$ for 10 minutes in a table-top microcentrifuge (Cooling Centrifuge, Eppendorf 5418R, Hamburg, Germany). $3.0 \mu$ of the supernatant was used as the template for PCR.

Isolates of $C$. perfringens from water samples were confirmed by amplifying $16 \mathrm{~S}$ rRNA gene of the $C$. perfringens as per Tanooka., et al. (2005) [22]. The $25 \mu \mathrm{l}$ reaction consisted of $3.0 \mu \mathrm{l}$ template DNA, $2.5 \mu \mathrm{l}$ of $10 \mathrm{X}$ buffer, $2.0 \mu \mathrm{l}$ of $\mathrm{MgCl}_{2}, 0.3 \mu \mathrm{l}$ of $25 \mathrm{mM}$ dNTP mix, $0.5 \mu \mathrm{l}$ each of forward and reverse primers, $1 \mathrm{U}$ of Taq DNA Polymerase (Fermentas Life Sciences, USA) and rest of sterile distilled water. Well characterized isolates of $C$. perfringens maintained in the Division of Veterinary Microbiology and Immunology, FVSc 
and AH, Shuhama, Ganderbal were used as positive control while sterile distilled water served as negative control. The primers used were procured from GCC Biotech, Kolkata, India and have the following sequence: forward- TAACCTGCCTCATAGAGT and reverseTTTCACATCCCACTTAATC. The PCR conditions in the thermal cycler (Mastercycler Gradient, Eppendorf AG, Germany) consisted of initial denaturation at $95^{\circ} \mathrm{C}$ for 5 minutes, followed by 35 cycles of denaturation at $94^{\circ} \mathrm{C}$ for 30 seconds, annealing at $49^{\circ} \mathrm{C}$ for 90 seconds and extension at $72^{\circ} \mathrm{C}$ for 90 seconds, followed by final extension at $72^{\circ} \mathrm{C}$ for 10 minutes.

\section{Bacterial load (CFU/ml) of $C$. perfringens in water samples}

For assessing the clostridial load of the Dal Lake, Serial dilution spread plate technique was used which is as follows:

1. Test tubes were arranged in the test tube stand and were labelled in a serial manner. All the tubes were filled with 9 ml autoclaved brain heart infusion broth (BHI, HiVeg ${ }^{\mathrm{TM}}$; Himedia Laboratories, Mumbai, India).

2. $1 \mathrm{ml}$ of the water sample was added into the first tube filled with $9 \mathrm{ml}$ of BHI broth. This gives 1:10 or $10^{-1}$ dilution.

3. Then, $1 \mathrm{ml}$ of the sample suspension was taken from the first tube and added into second tube containing $9 \mathrm{ml}$ of BHI broth. This gives $1: 100$ or $10^{-2}$ dilution.

4. In this manner, $10^{-3}, 10^{-4}$ and $10^{-5}$ dilutions were prepared.

5. One $\mathrm{ml}$ of first dilution was taken and inoculated on a sterile Sulfite Polymyxin Sulphadiazine agar plates (SPS HiVeg ${ }^{\mathrm{TM}}$ Agar, Modified; Hi-media Laboratories, Mumbai, India) using L-spreader.

6. This was repeated with all dilutions individually and separately.

7. All the plates were then incubated anaerobically in 3.5 litre anaerobic jars (Oxoid Limited, Thermo Fisher Scientific Inc., UK) with GasPak ${ }^{\mathrm{TM}}$ Anaerobe Container System (Becton, Dickinson and Company, USA) at $37^{\circ} \mathrm{C}$ for 24 hours.

8. Plates containing overlapping or diffused colonies were discarded (usually less than 30 or more than 300 colonies).

9. Plates showing distinct and well separated colonies were selected.

After incubation, the visibly distinguishable $C$. perfringens colonies were identified and the number on each plate was counted using digital colony counter pen (Hi-media, Mumbai, India).
Following formula was used to calculate Colony Forming Unit (CFU):

CFU

$$
=\frac{\text { Number of colonies counted } \mathrm{x} \text { Dilution factor }}{\text { Volume of water sample taken }(\mathrm{ml})}
$$

\section{Results}

The water samples after 48 hours of anaerobic incubation in cooked meat medium at $37^{\circ} \mathrm{C}$, showed turbidity with gas bubbling. On Sulphite Polymyxin Sulphadiazine (SPS) agar, C. perfringens colonies were typically creamish with black center. Isolated colonies were further subcultured on the SPS agar plates to obtain pure culture of $C$. perfringens (Figure 1).

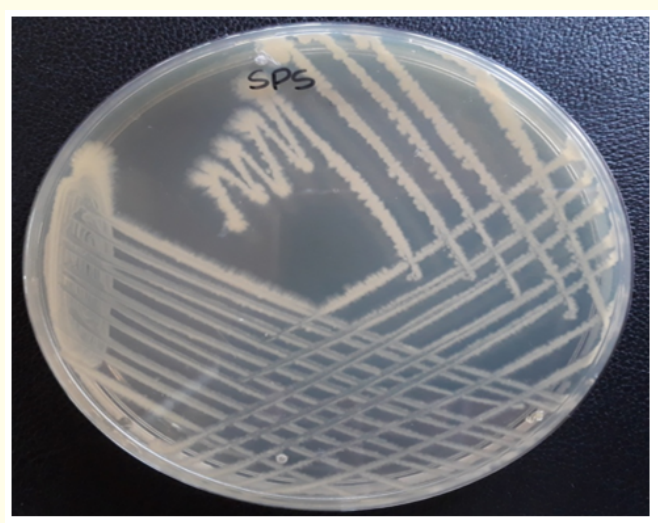

Figure 1: Cream coloured colonies of Clostridium perfringens on Sulphite Polymyxin Sulphadiazine (SPS) agar.

On Gram's staining, the black centered creamish colonies isolated on SPS agar revealed typical Gram-positive stout rods suggestive of $C$. perfringens at 1000X (Figure 2) using compound microscope (Olympus CX21, Olympus Corporation, Tokyo, Japan) with digital camera (10.0 MP Olympus $\varepsilon$-520, Olympus Imaging Corporation, China).

All the $45(100 \%)$ isolates from water samples were confirmed positive for $C$. perfringens when subjected to polymerase chain reaction (PCR) using species specific 16S rRNA gene amplification primers. These isolates which were morphologically identified as C. perfringens, amplified $481 \mathrm{bp}$ product corresponding to C. perfringens (Figure 3). 


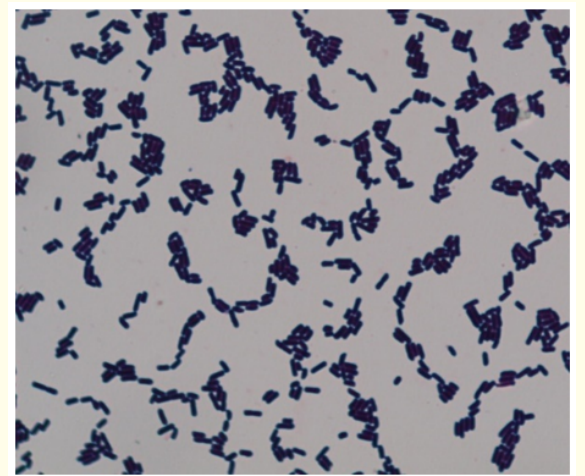

Figure 2: Gram stained smear of pure culture of Clostridium perfringens showing Gram positive violet rods under oil immersion (1000X).

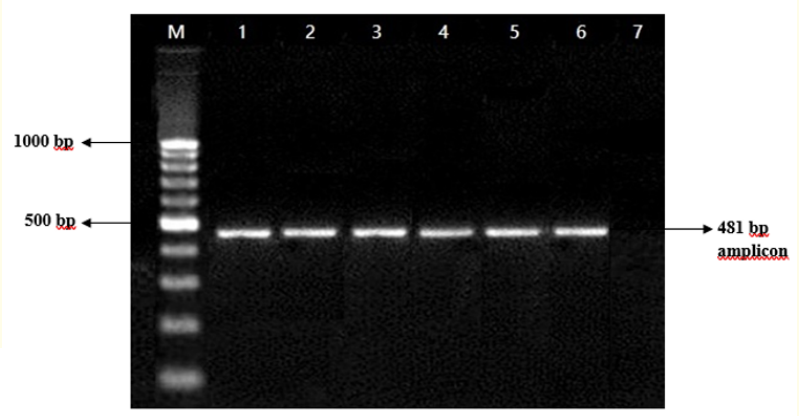

Figure 3: Detection of $16 \mathrm{~S}$ rRNA gene of Clostridium perfringens Lane M: 100bp DNA ladder

Lane 1: Positive control

Lane 2-6: Test sample of C. perfringens from wate Lane 7: Negative control.

The clostridial load in the water samples was assessed in terms of colony forming units (CFU/ml) (Figure 4). The overall C. perfringens load in Dal Lake at five different sites ranged between $9.2 \times 10$ $\mathrm{CFU} / \mathrm{ml}$ to $1.87 \times 10^{2} \mathrm{CFU} / \mathrm{ml}$. The highest average $\mathrm{CFU} / \mathrm{ml}$ value was found at Dalgate $\left(1.87 \times 10^{2}\right)$, followed by Telbal Nallah $(1.78$ $\left.\mathrm{x} 10^{2}\right)$, Dhobi Ghat $\left(1.20 \times 10^{2}\right)$, Centaur Lake View $\left(1.05 \times 10^{2}\right)$ and Char-Chinari ( $9.2 \times 10)$, respectively (Figure 5). Statistically, it was observed that there is a significant difference in average $\mathrm{CFU} / \mathrm{ml}$ values of $C$. perfringens at the five sites of the Dal Lake $(\mathrm{P}<0.01)$ as shown in the table 1.

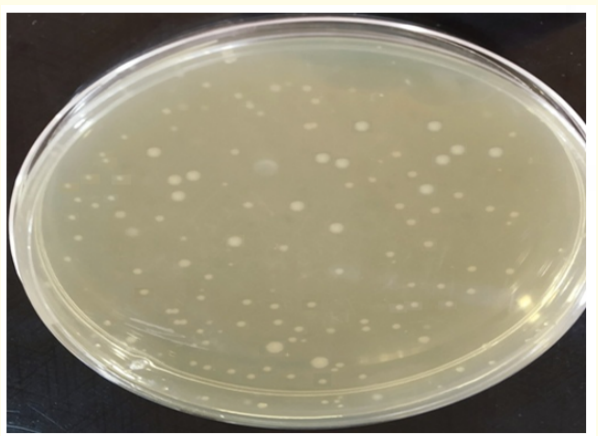

Figure 4: Colonies of Clostridium perfringens on SPS agar plate (Spread plate technique).

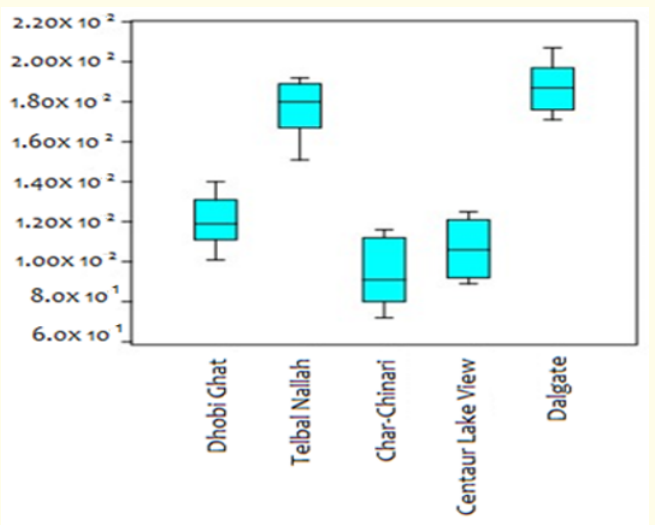

Figure 5: Boxplot showing average $\mathrm{CFU} / \mathrm{ml}$ values of Clostridium perfringens at 5 sites of the Dal Lake.

\begin{tabular}{|l|c|c|c|c|}
\hline Site & $\begin{array}{c}\text { CFU/ml (Mean } \\
\text { value) }\end{array}$ & $\begin{array}{c}\text { Standard } \\
\text { Error }\end{array}$ & F value & $\begin{array}{c}\text { P } \\
\text { value }\end{array}$ \\
\cline { 1 - 3 } Dhobi Ghat & $1.20 \times 10^{2}$ & 3.34 & \multirow{2}{*}{104.6} & $<0.01$ \\
\cline { 1 - 3 } Telbal Nallah & $1.78 \times 10^{2}$ & 4.24 & & \\
\cline { 1 - 3 } Char-Chinari & $9.2 \times 10$ & 4.85 & & \\
\cline { 1 - 3 } $\begin{array}{l}\text { Centaur Lake } \\
\text { View }\end{array}$ & $1.05 \times 10^{2}$ & 4.41 & & \\
\cline { 1 - 3 } Dalgate & $1.87 \times 10^{2}$ & 3.68 & & \\
\hline
\end{tabular}

Table 1: Distribution of average CFU/ $\mathrm{ml}$ values of Clostridium perfringens at five sites of the Dal Lake. 


\section{Discussion}

Water acts as a mode of transmission for $C$. perfringens to humans and animals which is then responsible for causing varied diseases like gas gangrene and food poisoning in humans, enterotoxaemia, hemorrhagic enteritis, necrotic enteritis and diarrhea in livestock animals and poultry [28]. In the present study, water samples from different sites of the Dal Lake were screened for the presence of $C$. perfringens.

The colonies formed by $C$. perfringens on SPS agar were typical round, umbonate, centrally dense with rhizoid periphery and slightly opaque. These findings are in agreement with those of Das and Jain (2012) and Wani., et al. (2018) [5,23]. The Gram's staining of the bacterial smears taken from the pure cultures of $C$. perfringens in the current study revealed typical Gram-positive short rods with blunt ends which correlated well with the reports of Das and Jain (2012), El-Shorbagy (2012) and Wani., et al. (2018) [5,6,23]. Based on PCR amplification of 16S rRNA gene, our study revealed that $45(100 \%)$ of 45 water samples were positive for $C$. perfringens.

According to Rios., et al. (2017), C. perfringens is believed to be an important indicator of faecal contamination in aquatic habitats [18]. For determining the bacterial load of $C$. perfringens in the Dal Lake, a total of 45 water samples from 5 different sites viz., Dhobi Ghat, Telbal Nallah, Char-Chinari, Centaur Lake View and Dalgate (9 samples from each site) were processed. The highest average $\mathrm{CFU} / \mathrm{ml}$ value was found at Dalgate $\left(1.87 \times 10^{2}\right)$ while as the lowest being observed at Char-Chinari ( $9.2 \times 10)$. The possible reason being, that the Dalgate site is more prone to direct impact from human interventions from within (house boats, vegetable gardens) and outside activities (households, hotels, restaurants, shops) and also from point and non point sources of sewage (domestic, agricultural as well as commercial). Moreover, greater tourist influx resulting in the increased movement of house boats in the Dal Lake esp., at Dalgate, where there is no proper disposal system for the night soil results in faecal pollution and deterioration of the water quality coupled with outburst of $C$. perfringens.

C. perfringens load in Dal Lake at different sites was found to be in the range of $9.2 \times 10 \mathrm{CFU} / \mathrm{ml}$ to $1.87 \times 10^{2} \mathrm{CFU} / \mathrm{ml}$, which is much less than the critical CFU level of $C$. perfringens $\left(10^{5}-10^{8}\right)$ to cause any toxinfection. However, it must be noted that the water source used for drinking or cleaning purpose should not contain any organism of faecal origin [7,24]. Saleem., et al. (2013) concluded that water of the Dal Lake is unfit for drinking purpose as per the standards of WHO after assessing the water quality by studying the coliform bacterial diversity of the lake [19].
The colonization of $C$. perfringens in aquatic habitats is mainly due to indiscriminate dumping of untreated commercial, agricultural or household wastes including sewage [11]. Colonization may also arise from naturally occurring small numbers of $C$. perfringens in aquatic environments [1]. These may have different origins in the study area, such as a result of animal wastes carried by run-off from catchment areas, deposition of fecal material by local as well as migratory birds or atmospheric transport of clostridial spores.

\section{Conclusion}

C. perfringens is present in the aquatic environment of the Dal Lake. C. perfringens load in Dal Lake was found to be much less than the critical CFU level of $C$. perfringens $\left(10^{5}-10^{8}\right)$ to cause any toxinfection. However, it must be noted the increasing anthropogenic activities in and around the Lake will eventually result in the elevated levels of this potent human and animal pathogen in its ecosystem and endanger the public health if its water is used for drinking, cooking or sanitary purposes. Thus, in light of the present study, there is a need to conduct an elaborate research on this organism in the various aquatic ecosystems of the valley in the near future in order to minimise its transmission to humans and livestock.

\section{Acknowledgement}

I owe my deep sense of gratitude to the Division of Veterinary Microbiology and Immunology, Shuhama, SKUAST K for providing the necessary support from NAE project on Anaerobic Bacteriology funded by ICAR.

\section{Conflict of Interest}

None.

\section{Bibliography}

1. Aschfalk A and Müller W. "Clostridium perfringens Toxin Types From Wild-caught Atlantic Cod (Gadus morhua L.), Determined By PCR And ELISA". Canadian Journal of Microbiology 48.4 (2002): 365-368.

2. Banday, M., et al. "Contamination of fresh water fish Schizothorax niger with chlorpyrifos from Dal Lake basins, India". International Journal of Pharma Sciences and Research 3.12 (2012): 535-542.

3. CDC. Center for Disease Control and Prevention. United States of America (USA). National Center for Emerging and Zoonotic Infectious Diseases (NCEZID). Division of Foodborne, Waterborne and Environmental Diseases (DFWED) (2017).

4. Croci L., et al. "Comparison of PCR, Electrochemical EnzymeLinked Immunosorbent Assays and the Standard Culture Method for Detecting Salmonella in Meat Products". Applied Environment Microbiology 70.3 (2004): 1393-1396. 
5. Das A and Jain A. "Clostridium perfringens Type A From Freshwater Fishes". International Journal of Advanced Biotechnology and Research 3.3 (2012): 680-687.

6. El-Shorbagy MM., et al. "Prevalence of Clostridium perfringens Alpha Toxin In Processed And Unprocessed Fish". International Journal of Microbiological Research 3.3 (2012): 195-199.

7. Fonseca LF. “Concentration of hardness, alkalinity and nitrate in Water Used for cleaning milk equipment in Brazilian dairy farms". Proc. Xth ISAH conference Maastricht, The Netherlands (2000): 100-103.

8. Gamboa-Coronado MDM., et al. "Molecular Characterization And Antimicrobial Resistance Of Clostridium perfringens Isolates Of Different Origins In Costa Rica". Journal of Tropical Biology 59.4 (2011): 1479-1485.

9. Jones AQ., et al. "Drinking water consumption patterns in British Columbia: an investigation of associations with demographic fac-tors and acute gastrointestinal illness". Science of the Total Environment 388 (2007): 54-65.

10. Kui R and Hall LJ. "An update on the human and animal enteric pathogen Clostridium perfringens". Emerging Microbes and Infections 7 (2018): 141.

11. Liston J. "Sanitation And The Seafood Industry". Association of Food and Drug Officials-Quarterly Bulletin 43 (1970): 158-162.

12. Massoc PA. "Diseases Associated With Food". Chilean Journal of Infectology 25.5 (2008): 395-397.

13. PAHO. Pan American Health Organization. World Health Organization. Codex Alimentarius. Sanitary Control. General Principles of Hygiene of Codex Foods (2015).

14. Pascual MDR and Calderón V. "Food Microbiology: Analytical Methodology for Food and Beverages, 2nd edition". Ediciones Diaz de Santos (2000).

15. Pommervilli JC. Alcamo's Fundamentals of Microbiology. 8th Ed. Massachusetts: Jones and Bartlett Publishing (2007).

16. Qadri H and Yousuf AR. "Dal Lake Ecosystem: Conservation Strategies And Problems". In: Sengupta, M. and Dalwani, R. (eds.), Proceedings of Taal 2007: The 12th world lake conference (2008): 1453-1457.

17. Quinn PJ., et al. "Veterinary Microbiology and Microbial Diseases". Wiley Blackwell (2011): 1-912.

18. Ríos-Tobón S., et al. "Pathogens And Microbiological Indicators Of Water Quality For Human Consumption". Journal of the National School of Public Health 35.2 (2017): 236-247.
19. Saleem S Kamili., et al. "Water Quality Assessment of Dal Lake, Kashmir Using the Coliforms as Indicator Bacteria". Journal on New Biological Reports 2.1 (2013): 30-35.

20. Santos G and Heredia N. "Clostridium perfringens: A Dynamic Food-Borne Pathogen". Food and Bioprocess Technology 4.4 (2011): 624-630.

21. Songer JG. "Clostridial Enteric Diseases of Domestic Animals". Clinical Microbiology Review 9.2 (1996): 216-234.

22. Tonooka T., et al. "Detection and Quantification of Four Species of the Genus Clostridium in Infant Feces". Microbiology and Immunology 49.11 (2005): 987-992.

23. Wani N., et al. "Isolation And Virulence Gene Profiling Of Clostridium perfringens From Freshwater Fish". Journal of Entomology and Zoology Studies 6.3 (2018): 176-181.

24. WHO. "Guidelines for drinking water quality". Geneva: World Health Organization 2 (1984): 3-60.

25. WHO. "Guidelines for drinking water quality". Geneva: World Health Organization 1 (1993): 1-29.

26. Williams RB. "Intercurrent Coccidiosis And Necrotic Enteritis Of Chickens: Rational, Integrated Disease Management By Maintenance Of Gut Integrity". Avian Pathology 34.3 (2005): 159-180.

27. Wani S. A., et al. "Investigation of diarrhoeic faecal samples for enterotoxigenic, Shiga toxin-producing and typical oratypical enteropathogenic Escherichia coli in Kashmir, India". FEMS Microbiological Letters 261 (2006): 238-244.

28. Yadav JP., et al. "Isolation, Genotyping And Antibiogram Profile Of Clostridium perfringens Isolates Recovered From Freshwater Fish And Fish Products From Kolkata Region". Journal of Pure and Applied Microbiology 10.4 (2016): 2807-2814.

\section{Assets from publication with us}

- Prompt Acknowledgement after receiving the article

- Thorough Double blinded peer review

- Rapid Publication

- Issue of Publication Certificate

- High visibility of your Published work

Website: https://www.actascientific.com/ Submit Article: https://www.actascientific.com/submission.php Email us: editor@actascientific.com Contact us: +919182824667 